\title{
Effect of two erosive protocols using acidic beverages on the shear bond strength of orthodontic brackets to bovine enamel
}

\author{
Catielma Nascimento Santos², Felipe de Souza Matos², Sigmar de Mello Rode \\ Paulo Francisco Cesar ${ }^{4}$, Flávia Pardo Salata Nahsan ${ }^{5}$, Luiz Renato Paranhos ${ }^{6}$
}

DOI: https://doi.org/10.1590/2177-6709.23.6.064-072.oar

Objective: To assess the short-term effect of two in vitro erosive challenge protocols on the bond strength of metal orthodontic brackets on bovine enamel. Methods: Sixty bovine incisors were selected and randomly divided into six groups: AS7 (artificial saliva - 7 days, Control Group); CC7 (Coca-Cola ${ }^{\text {TM }}$ - 7 days); LJ7 (lime juice - 7 days); AS30 (artificial saliva - 30 days, Control Group); CC30 (Coca-Cola ${ }^{\text {TM }}$ - 30 days); LJ30 (lime juice - 30 days). Microhardness testing was performed prior to the erosive challenge to verify the standardization of samples. Immersion was performed $4 \mathrm{x} /$ day for five minutes, for either 7 or 30 days. After immersions were concluded, the brackets were bonded and shear bond strength was assessed after 48 hours. The Adhesive Remnant Index (ARI) was also assessed. Data were analyzed by two-way ANOVA, followed by Tukey's post-hoc and Student's $t$ test for paired samples, and the Kruskal-Wallis non-parametric test $(a=5 \%)$. Results: The mean and standard deviation of microhardness testing of total samples were $281.89 \pm 44.51 \mathrm{KHN}$. There was no statistically significant difference in shear bond strength for the time factor ( 7 or 30 days; $\left.\mathrm{F}_{5.54}=0.105 ; p=0.901\right)$. However, there was a statistically significant difference for the solution factor $\left(\mathrm{F}_{5.54}=6.671\right.$; $p=0.003)$. These differences occurred among solutions of Saliva $\mathrm{x}$ Coca-Cola ${ }^{\mathrm{TM}}(p=0.003)$ and Coca-Cola ${ }^{\mathrm{TM}} \times$ Lime Juice $(\mathrm{p}=0.029)$. The assessment of the Adhesive Remnant Index showed no significant difference between groups. Conclusions: The immersion time used in the erosion protocols did not affect the bond strength of brackets to teeth. Coca-Cola ${ }^{\mathrm{TM}}$ induced significantly higher shear bond strength values than lime juice and artificial saliva. However, the short term effects of 7/30 days in this in vitro study may not be extrapolated for in vivo ones. Clinical studies should be conducted, substantiating the laboratory results. Keywords: Erosion. Orthodontics. Orthodontic brackets. Shear strength.

Objetivo: avaliar o efeito de curto prazo de dois protocolos de desafio erosivo, in vitro, na resistência adesiva de braquetes ortodônticos metálicos em esmalte bovino. Métodos: Sessenta incisivos bovinos foram selecionados e divididos aleatoriamente em seis grupos: SA7 (saliva artificial - 7 dias, Grupo Controle); CC7 (Coca-Cola ${ }^{\circledR} 7$ dias); SL7 (suco de limão - 7 dias); SA30 (saliva artificial - 30 dias, Grupo Controle); CC30 (Coca-Col ${ }^{\circledast}$ - 30 dias); SL30 (suco de limão - 30 dias). Foi realizado o teste de microdureza antes do desafio erosivo, para verificar a padronização das amostras. A imersão foi realizada quatro vezes ao dia, por cinco minutos, durante 7 ou 30 dias. Finalizadas as imersões, os braquetes foram colados e, após 48 horas, foi avaliada a resistência ao cisalhamento. O Índice de Adesivo Remanescente (IAR) também foi avaliado. Para análise dos dados, foram utilizados os testes ANOVA dois fatores, seguido do post-hoc de Tukey e teste $t$ de Student para amostras pareadas, e o teste não-paramétrico de Kruskal-Wallis $(\alpha=5 \%)$. Resultados: a média e o desvio-padrão do teste de microdureza das amostras totais foi igual a $281,89 \pm 44,51 \mathrm{KHN}$. Não houve diferença estatisticamente significativa na resistência ao cisalhamento para o fator tempo (7 ou 30 dias; $\left.\mathrm{F}_{5,54}=0,105 ; p=0,901\right)$. Contudo, houve diferença estatisticamente significativa para o fator solução $\left(\mathrm{F}_{5,54}=6,671 ; p=0,003\right)$. Essas diferenças ocorreram entre as soluções de Saliva $x \mathrm{Coca}^{-C o l}{ }^{\circledR}(p=0,003)$ e Coca-Cola ${ }^{\circledR} x$ suco de limão $(p=0,029)$. Ao avaliar o Índice de Adesivo Remanescente, não foi possível verificar diferença significativa entre os grupos. Conclusões: o tempo de imersão utilizado nos protocolos de erosão não afetou a resistência de união dos braquetes aos dentes. A Coca-Cola ${ }^{\circledR}$ induziu valores de resistência ao cisalhamento significativamente mais altos do que o suco de limão e a saliva artificial. No entanto, os efeitos em curto prazo de 7 e 30 dias, nesse estudo in vitro, não podem ser extrapolados para os estudos in vivo. Estudos clínicos devem ser conduzidos, fundamentando os resultados laboratoriais. Palavras-chave: Erosão. Ortodontia. Braquetes ortodônticos. Resistência ao cisalhamento.

\footnotetext{
'Universidade Federal de Sergipe, Programa de Pós-graduação em Odontologia (Aracaju/SE, Brazil).

${ }^{2}$ Universidade Estadual Paulista, Instituto de Ciência e Tecnologia, Programa de Pós-Graduação em Odontologia Restauradora (São José dos Campos/SP, Brazil).

${ }^{3}$ Universidade Estadual Paulista, Instituto de Ciência e Tecnologia,

Departamento de Materiais Dentários e Prótese (São José dos Campos/SP, Brazil).

${ }^{4}$ Universidade de São Paulo, Faculdade de Odontologia, Departamento de Biomateriais e Biologia Oral (São Paulo/SP, Brazil).

${ }^{5}$ Universidade Federal de Sergipe, Departamento de Odontologia (Lagarto/SE, Brazil).

${ }^{6}$ Universidade Federal de Uberlândia, Faculdade de Odontologia (Uberlândia/ MG, Brazil).
}

How to cite: Santos CN, Matos FS, Rode SM, Cesar PF, Nahsan FPS, Paranhos LR. Effect of two erosive protocols using acidic beverages on the shear bond strength of orthodontic brackets to bovine enamel. Dental Press J Orthod. 2018 NovDec;23(6):64-72. DOI: https://doi.org/10.1590/2177-6709.23.6.064-072.oar

Submitted: June 22, 2017 - Revised and accepted: February 17, 2018
» The authors report no commercial, proprietary or financial interest in the products or companies described in this article.

Contact address: Luiz Renato Paranhos Av. Pará, 1720, bloco 2G, sala 1, bairro Umuarama CEP: 38.405-320 - Uberlândia/MG - Brasil

E-mail: paranhos.1rp@gmail.com 


\section{INTRODUCTION}

Dental erosion is a problem with increasing incidence in the worldwide population. ${ }^{1}$ This type of dental lesion is characterized by wear on the tooth surface caused by a chemical process involving the activity of acids, without the involvement of bacteria. ${ }^{2}$ Erosion has a multifactorial etiology and is related to intrinsic and extrinsic factors. Intrinsic factors are related to endogenous acids produced by the human body and commonly present in individuals with bulimia or diseases affecting the gastrointestinal tract. ${ }^{3}$ The extrinsic factors are related to exogenous acids found in foods and beverages. ${ }^{2}$

Several commercially available acidic beverages accelerate the erosion process, such as citric acidbased $^{4-8}$ and cola-based ${ }^{3,4,7-14}$ drinks, energy drinks, ${ }^{15}$ and isotonic drinks. ${ }^{4}$ The erosive potential of these beverages is related to their low $\mathrm{pH}$ and low buffering capacity. Acidic foods and beverages with $\mathrm{pH}$ lower than 5.5 may cause the dissolution of hydroxyapatite and fluorapatite present in tooth enamel. ${ }^{5}$

Tooth enamel is a mineralized tissue and its microstructure influences the bonding mechanism involving this substrate and the bracket. ${ }^{1}$ A satisfactory bond between bracket and enamel is crucial for the success of the orthodontic treatment, considering that the bonded bracket, apart from the fact that it will eventually be removed, should resist the orthodontic forces and the masticatory loads occurring during the treatment. ${ }^{16}$ Oncag et al ${ }^{13}$ found that carbonated beverages, such as CocaCola $^{\mathrm{TM}}$ and Sprite ${ }^{\mathrm{TM}}$, negatively affected the retention force of brackets bonded to enamel previously subjected to an erosion process. On the other hand, Khoda et $\mathrm{a}^{14}$ showed that the intake of acidic beverages does not decrease the bond strength of orthodontic brackets to tooth enamel.

Some behavioral factors such as eating habits may change bracket bond strength to enamel during orthodontic treatment. The $\mathrm{pH}$ of beverages, type of acid present, buffering capacity of saliva, constant acidity ( $\mathrm{pKa}$ ), and concentrations of phosphate, calcium, fluoride and phosphorus may influence the erosion of hard dental tissues. ${ }^{3,10-12} \mathrm{Few}$ current studies correlate the bonding of orthodontic attachments in previously eroded enamel and its potential complications. ${ }^{17}$
This study aimed to assess the effect of storage time in the erosive solution and the effect of the substance used in the erosive challenge on the bond strength of metal orthodontic brackets bonded to bovine enamel. The null hypotheses were: [1] there would be no differences on the bond strength of the brackets to enamel due to the different immersion times, and [2] the different solutions would not affect the bond strength of the brackets to enamel.

\section{MATERIAL AND METHODS}

This in vitro study was carried out with 60 bovine central incisors. Based on the study by Pasha et al, ${ }^{18}$ who found the highest standard deviation of the groups equal to $2.74 \mathrm{MPa}$, at $5 \%$ significance level, in order to prove that 7 elements per group are required to detect a minimum difference of $2.5 \mathrm{MPa}$ among groups. Predicting potential losses, the number of 10 elements ${ }^{13,18}$ per group was adopted. These teeth were sectioned in sizes of $7 \times 7 \times 2 \mathrm{~mm}$, at the flattest central region of the buccal aspect in the cervical-incisal and mesiodistal directions, forming enamel blocks, ${ }^{7}$ and poured in acrylic resin within a polyvinyl chloride (PVC) tube. The same evaluator performed all the procedures.

The random distribution of specimens in their respective groups was performed as follows: specimens were numbered from 1 to 60, placed in one single recipient, and picked one by one to compose the groups. The groups were separated by time (7 and 30 days) and by the beverage used (CocaCola [CC], Lime Juice [LJ] and artificial saliva [AS]), arranged as follows: AS7; CC7; LJ7; AS30; CC30; LJ30 (Fig 1).

The surfaces were flattened and polished in order to standardize the specimens and prepare them for the dental microhardness test. Therefore, \#320, \#600, and \#1200 silicon carbide grit papers ${ }^{9,12,19-21}$ (Norton $^{\mathrm{TM}}$, Guarulhos/SP, Brazil) were used for 30 seconds in high rotation and refrigeration in the polisher (Politriz Polipan ${ }^{\mathrm{TM}}$ 2, São Paulo/SP, Brazil).

\section{Assessment of dental microhardness testing}

In order to verify the standardization of enamel surface hardness ${ }^{19}$ a microhardness tester (FM 700, Future Tech Corp., Tokyo, Japan) was used, as well as a Knoop indenter with $100 \mathrm{~g}$ of static load, for 
5 seconds on enamel (Fig 2). Three indentations were made on the same specimen according to the following protocol ${ }^{19}$ : one indentation to the right, one in the middle, and one to the left, with distance of $100 \mu \mathrm{m}$ separating each indentation. ${ }^{5}$ To conclude the test, samples were subjected to the erosive process with the selected beverages.

\section{Measurement of $\mathrm{pH}$}

The $\mathrm{pH}$ was measured in a previously calibrated bench $\mathrm{pH}$ meter (Q400AS Quimis ${ }^{\mathrm{TM}}$, Diadema/SP, Brazil). Thirty $\mathrm{mL}$ of each compound were placed in a test tube and tested in the glass electrode of the

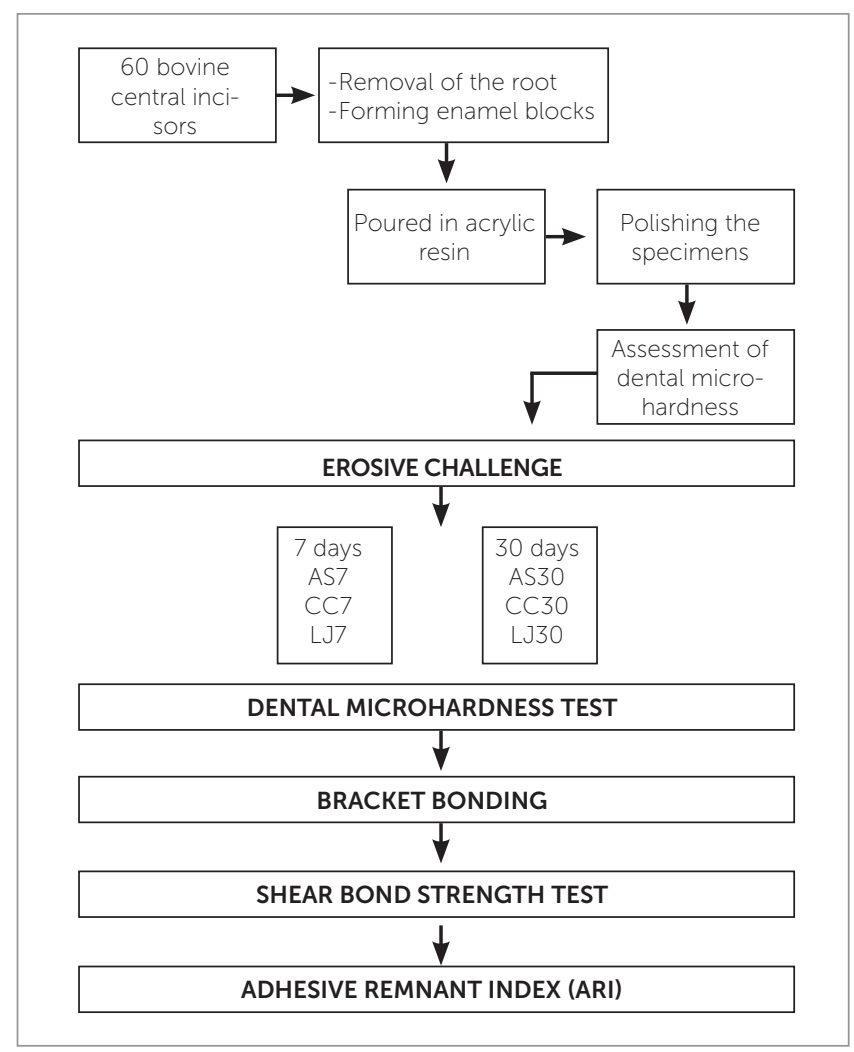

Figure 1 - Flowchart of the method design of the study.
$\mathrm{pH}$ meter, and the value obtained was shown in the ATT digital display. ${ }^{4}$ The operation was repeated three times with a five-minute interval, to standardize and certify the values obtained in the test (Table 1).

\section{Immersion method}

Immersion cycles were performed by submerging specimens in the specific solution for five minutes, ${ }^{4}$ four times a day $\left(8 \mathrm{~h}, 12 \mathrm{~h}, 16 \mathrm{~h}\right.$, and 20h), ${ }^{20}$ under agitation, for seven ${ }^{19}$ and 30 days. $^{4}$ The solutions composition is described in Table 1. After each immersion cycle, the specimens were washed in distilled water, dried in absorbent paper, and immersed in $15 \mathrm{~mL}$ of artificial saliva; then they were incubated at $37^{\circ} \mathrm{C}$ until the immersion procedure. ${ }^{4}$ In the AS7 and AS30 groups, specimens were immersed in artificial saliva for the selected time. Saliva was changed weekly ${ }^{4}$ for groups AS30, CC30, and LJ30, due to the longer testing period. After all immersions were concluded, the specimens were kept in distilled water at room temperature.

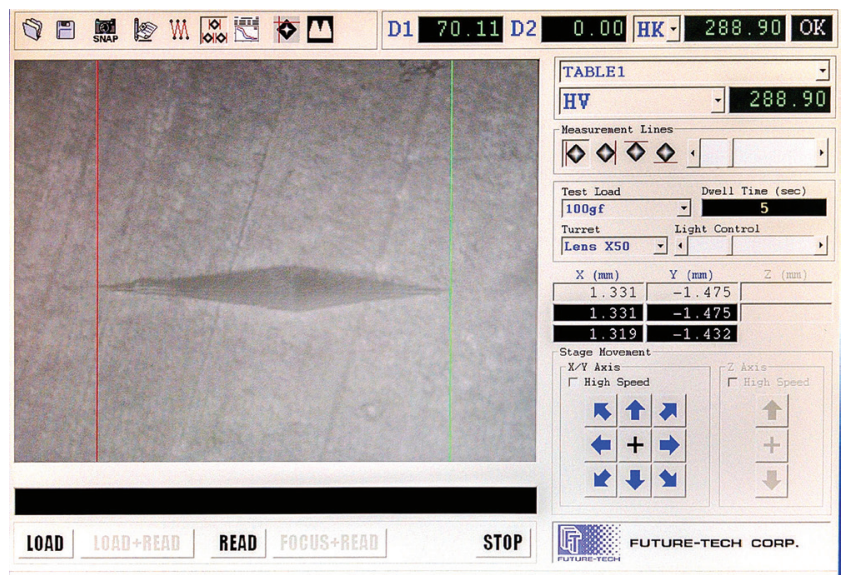

Figure 2 - Indentation performed by Knoop microdurometer. Red and green lines delimiting the indentation size.

Table 1 - Description of solutions composition and their $\mathrm{pH}$ value.

\section{Immersion solution}

Artificial saliva
Composition

$\mathrm{Ca}\left(\mathrm{NO}_{3}\right)_{2} ; \mathrm{H}_{2} \mathrm{O} 1.5 \mathrm{mmol} / \mathrm{L}$

$\mathrm{Na}_{2} \mathrm{HPO}_{4} ; 2 \mathrm{H}_{2} \mathrm{O} 0.9 \mathrm{mmol} / \mathrm{L}$

$\mathrm{KCl} 150 \mathrm{mmol} / \mathrm{L}$
6.5

pH value

$\mathrm{H}_{2} \mathrm{NC}\left(\mathrm{CH}_{2} \mathrm{OH}\right)_{3}(\mathrm{TRIS}) 0,1 \mathrm{~mol} / \mathrm{L}$

$\mathrm{NaF} 0,05 \mu \mathrm{g} / \mathrm{mL}$

Coca-Cola ${ }^{\text {TM }}$

Natural OneTM lime juice
Carbonated water, sugar, kola nut extract, caffeine caramel coloring IV, acidulant INS 338 and natural aroma

Lime juice without preservatives, with sugar
277 


\section{Bonding procedure}

The metal orthodontic brackets, Roth prescription, with 0.022-in slot (3M Unitek, São José do Rio Preto/ SP, Brazil), were bonded to bovine tooth surfaces with Transbond $^{\mathrm{TM}}$ XT orthodontic adhesive system (3M Unitek, Monrovia, CA, USA). Prophylaxis was previously performed with an extra-thin pumice (S.S. White, Rio de Janeiro/RJ, Brazil) and distilled water solution with a Robinson brush (Microdont, São Paulo/SP, Brazil) for 10 seconds in low-rotation handpiece (Kavo, Joinville/SC, Brazil), and water sprayed (manufacturer's recommendation). Acid-etching was performed with
37\% phosphoric acid (Dentsply, Petrópolis/RJ, Brazil) for 30 seconds on the dental surface, followed by water spraying and air-drying. Next, a primer was applied to the etched sample according to the manufacturer's protocol and light-cured for 15 seconds.

The adhesive was applied with a syringe (from the Transbond ${ }^{\mathrm{TM}}$ XT kit) using a sufficient amount to completely fill the base of the bracket. Then, the bracket was lightly placed on the dental surface aided by orthodontic tweezers, and pressed to remove excesses. The structure composed by tooth/adhesive system/bracket was light-cured for 20 seconds.
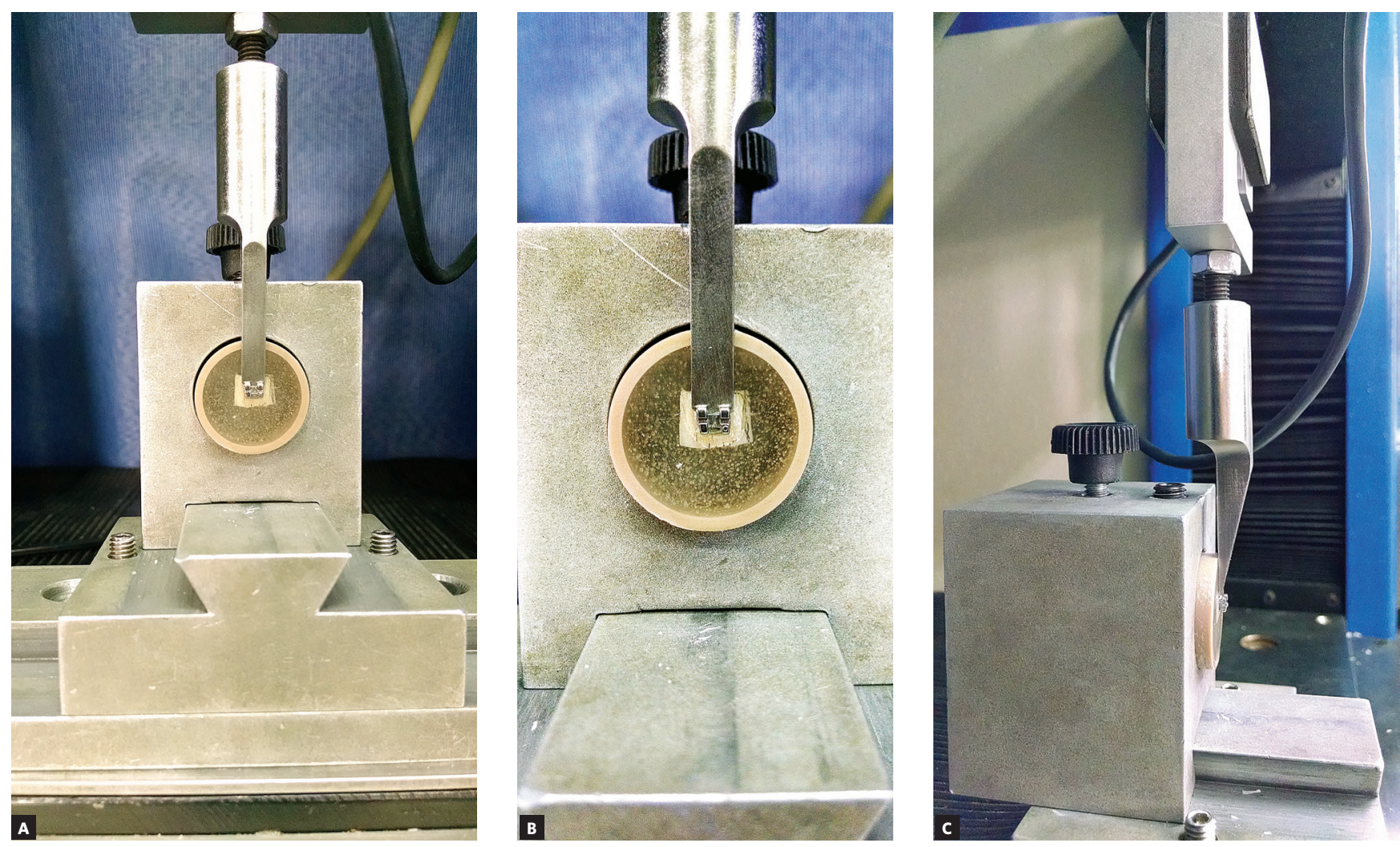

Figure 3 - Shear test at EMIC: A) front view; B) position of the chisel tip on the upper surface of the bracket; C) side view performing the test. 


\section{Shear bond strength test}

Specimens were subjected to the shear bond strength test using a universal testing machine (EMIC DL-1000, São José dos Pinhais/PR, Brazil) with $10 \mathrm{KN}$ maximum capacity, $50 \mathrm{KgF}$ cell load ${ }^{21}$ and $0.5 \mathrm{~mm} / \mathrm{min}$ crosshead speed, ${ }^{5} 48$ hours ${ }^{22-23}$ after bonding the orthodontic attachments.

Specimens were positioned in the testing machine so that the vertical rod of the shearing machine was perpendicular to the incisal edge of the bracket (flattest part), close to enamel surface, and parallel to the latter (Fig 3), in such a way that the force was perpendicular to the orthodontic bracket during the test. ${ }^{5}$ The force required for detachment was obtained in Kilograms-force $(\mathrm{KgF})$, then converted into Newtons $(\mathrm{N})$, and finally recorded and divided by the bonding area (area of the base of the bracket $=12.89 \mathrm{~mm}^{2}$ ), thus obtaining bond strength values in MegaPascal (MPa).

\section{Adhesive Remnant Index (ARI)}

After shear test, the Adhesive Remnant Index (ARI) was assessed with a stereoscope (SteREO Discovery. V20, Zeiss, Germany) with $10 x$ magnification.

Any adhesive remaining after bracket removal was assessed according to the ARI. ${ }^{24}$ The ARI scale ranges from 5 to 1 , where 5 indicates that no composite remained on the enamel; $4=$ less than $10 \%$ of the composite remained on the tooth surface; $3=$ between $10 \%$ and $90 \%$ of the composite remaining; $2=$ more than $90 \%$ remained on the tooth, and 1 = all composite remained on the tooth, along with the impression of the bracket base.

\section{Statistical analysis}

The Kolmogorov-Smirnov test was used to verify sample normality. Two-way ANOVA (solution factor and treatment time factor) was used for statistical analysis of data, followed by Tukey's post-hoc and Student's $t$ tests for paired samples. All analyses considered a significance level of 95\% and all tests were performed in the SPSS 16.0 software (IBM).

The Kruskal-Wallis non-parametric test was used to compare the six groups, regarding the ARI score.

All statistical procedures were performed in the Statistica software (StatSoft Inc., Tulsa, USA) version 13.

\section{RESULTS}

The sample showed normal distribution according to the Kolmogorov-Smirnov test $(p=0.77)$. The mean value ( \pm standard deviation) of enamel microhardness was $281.89 \pm 44.51 \mathrm{KHN}$.

Two-way ANOVA followed by Tukey's test showed significant effect only for the solution factor $\left(\mathrm{F}_{5.54}=6.671\right.$; $p=0.003)$, while the immersion time factor $\left(\mathrm{F}_{5.54}=1.282\right.$; $p=0.263)$ and the interaction among the factors studied were not statistically significant $\left(\mathrm{F}_{5.54}=0.105 ; \mathrm{p}=0.901\right)$. Figure 4 shows that Tukey's test identified a statistical difference among the bond strength values of Artificial Saliva versus Coca-Cola ${ }^{\mathrm{TM}}(\mathrm{p}=0.003)$ and Coca-Cola ${ }^{\mathrm{TM}}$ versus Lime Juice $(\mathrm{p}=0.029)$, regardless of the immersion time. The bond strength values obtained for the group immersed in Coca-Cola ${ }^{\mathrm{TM}}$ were significantly higher when compared to those of the groups subjected to Artificial Saliva and Lime Juice.

Table 2 - Rate of occurrences of ARI score, median score, and result of the comparison between the groups by the Kruskal-Wallis test.

\begin{tabular}{|c|c|c|c|c|c|c|c|c|}
\hline \multirow{2}{*}{ Time } & \multirow{2}{*}{ Solution } & \multicolumn{5}{|c|}{ ARI score* } & \multirow{2}{*}{$\begin{array}{c}\text { Median } \\
\text { score }\end{array}$} & \multirow{2}{*}{$\mathbf{p}$} \\
\hline & & 1 & 2 & 3 & 4 & 5 & & \\
\hline \multirow{3}{*}{7 days } & Saliva & $40 \%$ & $20 \%$ & $10 \%$ & $20 \%$ & $10 \%$ & 2 & \multirow{6}{*}{0.475} \\
\hline & Coca-Cola & $20 \%$ & $10 \%$ & $30 \%$ & $40 \%$ & $0 \%$ & 3 & \\
\hline & Lime juice & $40 \%$ & $30 \%$ & $10 \%$ & $20 \%$ & $0 \%$ & 2 & \\
\hline \multirow{3}{*}{30 days } & Saliva & $30 \%$ & $10 \%$ & $20 \%$ & $40 \%$ & $0 \%$ & 3 & \\
\hline & Coca-Cola & $30 \%$ & $0 \%$ & $20 \%$ & $0 \%$ & $50 \%$ & 4 & \\
\hline & Lime juice & $30 \%$ & $0 \%$ & $30 \%$ & $20 \%$ & $20 \%$ & 3 & \\
\hline
\end{tabular}

$* 1=$ all composite remained on tooth, 2 = more than $90 \%$ of composite remained on tooth, $3=$ between $10 \%$ and $90 \%$ remained on tooth, $4=$ less than $10 \%$ of composite on tooth, 5 = no composite on tooth. 


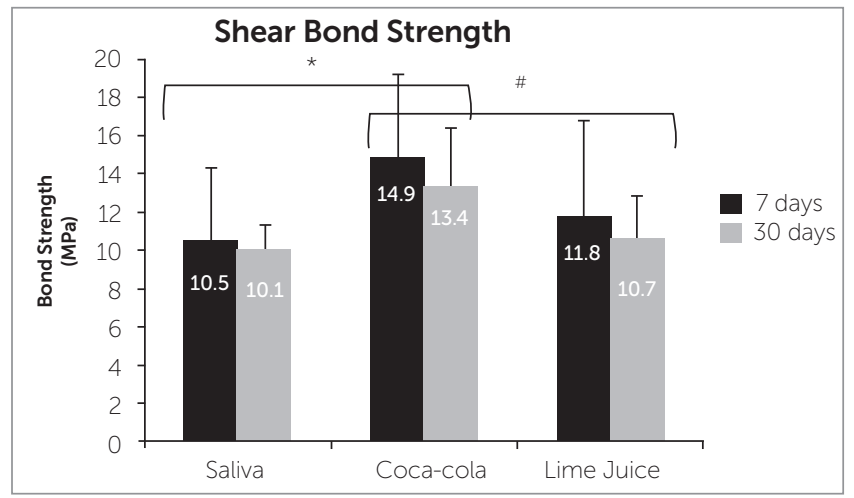

Figure 4 - Effect of the type of solution and immersion time on shear bond strength measurements. The values in the bars refer to the mean and standard deviation. The * and the \# represent statistically significant difference for the "solution" factor $\left(F_{554}=6.671 ; p=0.003\right)$ among solutions of Saliva $\times$ CocaCola $^{T M}(p=0.003)$ and Coca-ColaTM $x$ Lime Juice $(p=0.029)$.

Table 2 lists the ARI scores. In the 7-days protocol, both in Saliva and Lime Juice groups, 40\% of samples presented all the adhesive on the enamel surface. On the other hand, in the Coca-Cola ${ }^{\mathrm{TM}}$ group, $40 \%$ of samples indicated score 4 , that is, less than $10 \%$ of adhesive on the enamel surface. In the 30-days protocol, in the Saliva group, $40 \%$ of samples indicated score 4 , that is, less than $10 \%$ of adhesive on the enamel surface. In the Lime Juice group, scores 1 (all adhesive on teeth) and 3 (more than 10\% and less than $90 \%$ of adhesive on the enamel surface) were the most recurrent scores. In the Coca-Cola ${ }^{\mathrm{TM}}$ group, score 5 was mostly repeated, indicating no adhesive on the enamel surface.

\section{DISCUSSION}

The results of this study indicated that the storage in the erosive solutions (Coca-Cola ${ }^{\mathrm{TM}}$ and lime juice) did not affect the bond strength of the brackets to bovine enamel. However, the type of erosive solution had a significant effect on the bond strength, whereas immersion in Coca-Cola ${ }^{\mathrm{TM}}$ resulted in significantly higher mean values than those obtained after immersion in lime juice. Thus, the first null hypothesis was accepted and the second one was rejected.

There is a diversity of protocols of in vitro erosive challenges that range from three days ${ }^{10}$ to three month $s^{14}$ regarding immersion time; and from two ${ }^{13}$ to four ${ }^{16}$ times a day, regarding the number of immer- sions; there is also a great variation of types of food and beverages investigated. The literature shows a higher number of researches using Coca-Cola ${ }^{\mathrm{TM}},{ }^{3,4,7-14}$ followed by critic beverages ${ }^{4-8,14}$ such as lime-flavored soft drinks or lime juice. This research used CocaCola $^{\mathrm{TM}}$ and Natural One ${ }^{\mathrm{TM}}$ lime juice. Both have an acid $\mathrm{pH}\left(\mathrm{Coca}-\mathrm{Cola}^{\mathrm{TM}}=2.32\right.$, Lime Juice $\left.=2.77\right)$, favoring tooth enamel dissolution, which enables researches that induce the in vitro erosive challenge. ${ }^{2}$

Oncag et $\mathrm{al}^{13}$ induced erosion both in vivo and in vitro. The protocol adopted was the immersion for 5 minutes in predefined substances (Coca-Cola ${ }^{\mathrm{TM}}$ and Sprite ${ }^{\mathrm{TM}}$ ) and the control (artificial saliva), three times a day for three months. They noticed that there was no statistically significant difference between in vivo and in vitro groups. Khoda et al, ${ }^{14}$ tested only in vitro using a similar protocol (immersion for 5 minutes three times a day for three months); however, with drinks of similar brands (Pepsi $^{\mathrm{TM}}$ and 7Up Soda ${ }^{\mathrm{TM}}$ ). In the first work, the erosion caused by Coca-Cola ${ }^{\mathrm{TM}}$ and Sprite ${ }^{\mathrm{TM}}$ decreased the shear strength of the bracket to the enamel both in vivo and in vitro. In the second study, as a result, they observed that there was no negative effect on the shear strength in the bracket-enamel relationship. In addition to the difference in the drinks, the cementing agent may interfere with the final results as well as the time when the enamel was eroded before or after the bracket bonding. In works that simulated what would happen in vivo, there is also no homogeneity among protocols. Kato and Buzalaf ${ }^{12}$ used an in situ protocol by means of removable apparatus adapted with blocks of enamel, in which the individual removes the apparatus and immerses it in the substance in the predetermined time (immersion for 5 minutes, four times a day, for 5 days); and also observed wear on the surface of the enamel. In general, the difference among protocols hinders and prevents a more reliable comparison among results. In in vivo protocols it becomes even more difficult to discuss, due to the reduced number of papers and concerning with the ethical precepts.

In this research, two erosive challenge protocols were tested before bracket bonding. Immersion of the in vitro specimens was performed four times daily, for 5 minutes, over 7 and 30 days. It was observed that time does not influence the type of protocol. However, the beverages used during the experiment have a direct influence on the final result, as noted in other studies. ${ }^{13-14}$ 
There were statistically significant differences only for Coca-Cola ${ }^{\mathrm{TM}}$ in relation to the other solutions (Lime Juice and Saliva) in both 7 and 30 days, but when these storage time protocols ( 7 and 30 days) were compared within the same solution, it was not observed statistically significant difference. When substance $\mathrm{pH}$ is lower than 4 , as were the tested substances, saliva tends to become sub-saturated in hydroxyapatite and fluorapatite, limiting its remineralizing action and justifying the absence of complete remineralization on dental surfaces subjected to the erosive challenge. ${ }^{6,24}$ Fushida and Cury ${ }^{26}$ assessed the erosive effect of Coca-Cola ${ }^{\mathrm{TM}}$ on enamel and dentin and found no complete remineralization as well.

The statistically significant difference found for Coca-Cola ${ }^{\mathrm{TM}}$ in relation to lime juice in both storage times ( 7 and 30 days) may be justified by the different acids present in the composition of beverages. A study ${ }^{25}$ showed that the phosphoric acid present in Coca-Cola ${ }^{\mathrm{TM}}$ has higher erosive potential than the citric acid present in lime juice. Besides the different acids, factors such as $\mathrm{pH}$, mineral content, titratable acidity, and chelation properties of calcium may change the erosive potential of both beverages. ${ }^{2}$

The acids in Coca-Cola ${ }^{\mathrm{TM}}$ and lime juice lead to demineralization of dental inorganic matrix., ${ }^{4,25,27}$ The longer the exposure time to etiological factor, the greater the lesion size. ${ }^{24}$ However, the stability of enamel hydroxyapatite crystals in an erosive challenge may be maintained when phosphate, calcium, and/or fluoride ions are added. ${ }^{3,10-12}$ In this research, such ions weren't added to the tested substances.

Previous studies ${ }^{5,13,25}$ showed that when the erosive challenge was performed after bracket bonding, the shear bond strength decreased relative to the control group. This result may be justified by the degradation of the adhesive system around the attachment, in the bracket/adhesive system/tooth junction, stimulated by the acids present in the beverages. ${ }^{5,13,16}$ This research used a different method from the one previously mentioned, because the erosive challenge process was performed before orthodontic attachment bonding, simulating the erosive wear on enamel from the habit of drinking acidic beverages prior to the orthodontic treatment.

Reynolds $^{28}$ affirmed that a value of $4.9 \mathrm{MPa}$ seems reasonable for clinical success in order to maintain brackets bonded, considering they should bear this level of mastica- tory and orthodontic stresses without detachment. Sheibaninia et $\mathrm{a}^{29}$ found values ranging from 11 to $27 \mathrm{MPa}$ for shear bond strength, but without fractures. In the present research, the bond strength values found, after 7 and 30 days, were higher for groups immersed in Coca-Cola ${ }^{\mathrm{TM}}$ (14.9 and 13.4 MPa) and lime juice (11.8 and 10.7 MPa) than the values obtained for the control group with artificial saliva (10.5 and $10.1 \mathrm{MPa})$. Pasha et $\mathrm{al}^{18}$ showed that the erosive challenge with Coca-Cola ${ }^{\mathrm{TM}}$ presents higher shear strength and greater superficial wear on enamel than other substances. Barac et $\mathrm{a}^{30}$ assessed enamel roughness after immersion in five beverages, including Coca-Cola ${ }^{\mathrm{TM}}$, which presented a higher erosion potential and resulted in higher superficial roughness on enamel than the other substances. It is suggested that roughness may be one of the factors that influence enamel/adhesive system interlocking, possibly inducing higher shear bond strength.

The Adhesive Remnant Index was used to assess the pattern of adhesive failure, and there was no statistically significant difference between groups, as reported by Baka et al. ${ }^{31}$ Sajadi et al. ${ }^{16}$ obtained the same result, but identified higher tendency of adhesive to remain on the bracket mesh rather than on enamel, as in the present study. This suggests a higher connection between orthodontic bracket and adhesive than between adhesive and enamel. Both Sajadi et al. ${ }^{16}$ and Baka et al. ${ }^{31}$ showed in their results that the most recurrent ARI was the one where the adhesive remained in full or almost completely on the orthodontic attachment mesh. Sheibaninia et al ${ }^{29}$ affirm that, when this pattern occurs, it is for lacking a connection between adhesive system and tooth enamel.

This investigation showed that teeth subjected to constant erosive induction and requiring posterior bracket bonding may suffer higher resistance when removing orthodontic attachments. However, these in vitro results may not be extrapolated for in vivo conditions. Clinical studies should be conducted, substantiating the laboratory results.

\section{CONCLUSIONS}

The immersion time used in the erosion protocols did not affect the bond strength of brackets to teeth after 7 and 30 days of in vitro erosive challenges. Regarding the influence of the acidic beverages on the adhesion of orthodontic brackets, the immersion of bovine teeth in Coca-Cola ${ }^{\mathrm{TM}}$ induced significantly higher shear bond strength values than the immersion in lime juice and artificial saliva. 


\section{Acknowledgements}

The authors would like to thank FAPITEC/SE (Foundation for Research and Technological Innovation Support of the State of Sergipe) and CAPES (Coordination for the Improvement of Higher Education Personnel) for funding the execution of this work through PROMOB.
1. Jaeggi T, Lussi A. Prevalence, incidence and distribution of erosion. Monogr Oral Sci. 2006:20:44-65.

2. Lussi A, Hellwing E, Zero D, Jaeggi T. Erosive tooth wear: diagnosis, risk factors and prevention. Am J Dent. 2006 Dec;19(6):319-25

3. Pereira HABS, Leite AL, Italiani FM, Kato MT, Pessan JP, Buzalaf MAR Supplementation of soft drinks with metallic ions reduces dissolution of bovine enamel. J Appl Oral Sci. 2013 July-Aug;21(4):363-8

4. Leme RMP, Farias RA, Gomes JB, Mello JDB, Castro-Filice LS. Comparison in vitro of the effect of acidic drinks in the development of dental erosion analysis by scanning electron microscopy. Biosci J. 2011;27(1):162-9.

5. Hammad SM, Enan ET. In vivo effects of two acidic soft drinks on shear bond strength of metal orthodontic brackets with and without resin infiltration treatment. Angle Orthod. 2013 July; 83(4):648-52.

6. Cruz JB, Bonini G, Lenzi TL, Imparato JCP, Raggio DP. Bonding stability of adhesive systems to eroded dentin. Braz Oral Res. 2015;29(1):1-6

7. Fujii M, Kitasako Y, Sadr A, Tagami J. Roughness and pH changes of enamel surface induced by soft drinks in vitro-applications of stylus profilometry, focus variation 3D scanning microscopy and micro $\mathrm{pH}$ sensor. Dent Mater J. 2011;30(3):404-10

8. Low IM, Alhuthali A. In-situ monitoring of dental erosion in tooth enamel when exposed to soft drinks. Mater Sci Eng C Mater Biol Appl 2008;28(8):1322-5

\section{Author's Contribution (ORCID ${ }^{(0)}$}

Catielma N. Santos (CNS): 0000-0003-3932-5550

Felipe de Souza Matos (FSM): 0000-0001-5619-3831

Sigmar de Mello Rode (SMR): 0000-0002-4261-4217

Paulo Francisco Cesar (PFC): 0000-0001-5834-105X

Flávia P. S. Nahsan (FPSN): 0000-0002-3547-8886 ${ }^{\circledR 0}$

Luiz Renato Paranhos (LRP): 0000-0002-7599-0120

Conception or design of the study: CNS, FPSN, LRP. Data acquisition, analysis or interpretation: CNS, FSM, SMR, PFC, FPSN, LRP. Writing the article: CNS, PFC, LRP. Critical revision of the article: CNS, FSM, SMR, PFC, FPSN, LRP. Final approval of the article: CNS, FSM, SMR, PFC, FPSN, LRP. Obtained funding: LRP. Overall responsibility: CNS, FSM, SMR, PFC, FPSN, LRP.
9. Barbosa CS, Montagnolli LG, Kato MT, Sampaio FC, Buzalaf MAR. Calcium glycerophosphate supplemented to soft drinks reduces bovine enamel erosion. J Appl Oral Sci. 2012 July-Aug:20(4):410-3

10. Eygen IV, Vannet BV, Wehrbein $\mathrm{H}$. Influence of a soft drink with low pH on enamel surfaces: an in vitro study. Am J Orthod Dentofacial Orthop. 2005 Sept;128(3):372-7.

11. Kato MT, Sales-Peres SHC, Buzalaf MAR. Effect of iron on acid demineralization of bovine enamel block by a soft drink. Arch Oral Biol. 2007 Nov: 52(11):1109-11

12. Kato MT, Buzalaf MAR. Iron supplementation reduces the erosive potential of a cola drink on enamel and dentin in situ. J Appl Oral Sci. 2012 May-June:20(3):318-22.

13. Oncag G. Tuncer AV, Tosun YS. Acidic soft drinks effects on the shear bond strength of orthodontic brackets and a scanning electron microscopy evaluation of the enamel. Angle Orthod. 2005 Mar;75(2):24753.

14. Khoda MO, Heravi F, Shafaee H, Mollahassani H. The effect of different soft drinks on the shear bond strength of orthodontic brackets] Dent (Tehran). 2012 Spring:9(2):145-9

15. Owens BM, Kitchens $M$. The erosive potential of soft drinks on enamel surface substrate: an in vitro scanning electron microscopy investigation. J Contemp Dent Pract. 2007 Nov 1;8(7):11-20. 
16. Sajadi SS, Amirabadi GE, Sajadi S. Effects of two soft drinks on shear bond strength and adhesive remnant index of orthodontic metal brackets. J Dent (Tehran). 2014 July;11(4):389-97

17. Costenoble A, Vennatb E, Attalc JP, Dursund E. Bond strength and interfacial morphology of orthodontic brackets bonded to eroded enamel treated with calcium silicate-sodium phosphate salts or resin infiltration. Angle Orthod. 2016 Nov; 86(6):909-16.

18. Pasha A, Sindhu D, Nayak RS, Mamatha J, Chaitra KR, Vishwakarma S. The effect of two soft drinks on bracket bond strength and on intact and sealed enamel: an in vitro study. J Int Oral Health. 2015:7(Suppl 2):26-33.

19. Casas-Apayco LC, Driebi VM, Hipolito AC, Graeff MSZ, Rios D, Magalhães AC, et al. Erosive cola-based drinks affect the bonding to enamel surface: an in vitro study. J Appl Oral Sci. 2014 Sept-Oct;22(5):434-41.

20. Rios D, Honório HM, Magalhães AC, Delbem ACB, Machado MAAM, Silva SMB, et al. Effect of salivary stimulation on erosion of human and bovine enamel subjected or not to subsequent abrasion: an in situ/ex vivo study. Caries Res. 2006:40(3):218-23

21. Bezerra GL, Torres CRG, Tonetto MR, Borges AH, Kuga MC, Bandeca MC, et al. Shear bond strength of orthodontic brackets fixed with remineralizing adhesive systems after simulating one year of orthodontic treatment. Sci World J. 2015:2015:903451.

22. Rastelli MC, Coelho U, Jimenez EEO. Evaluation of shear bond strength of brackets bonded with orthodontic fluoride- releasing composite resins. Dental Press J Orthod. 2010;15(3):106-13.

23. Kawakami RY, Pinto AS, Gonçalves JR, Sakima MT, Gandini LG Jr. Avaliação "in vitro" do padrão de descolagem na interface de fixação de materiais adesivos ortodônticos ao esmalte de dentes inclusos: resistência ao cisalhamento após 48 horas e 10 dias. Rev Dental Press Ortod Ortop Facial. 2003:8(6):43-61.
24. Bishara SE, Trulove TS. Comparisons of different debonding ceramic brackets: an in vitro study technique for part II. Findings and clinical implications. Am J Orthod Dentofacial Orthop. 1990 Sept;98(3):263-73.

25. Navarro R, Vicente A, Ortiz AJ, Bravo LA. The effects of two soft drinks on bond strength, bracket micro leakage, and adhesive remnant on intact and sealed enamel. Eur J Orthod. 2011 Feb;33(1):60-5.

26. Fushida CE, Cury JA. Estudo in situ do efeito da freqüência de ingestão de Coca-Cola na erosão do esmalte-dentina e reversão pela saliva. Rev Odontol Univ São Paulo. 1999:13(2):127-34.

27. Lussi A, Jaeggi T. Erosion - diagnosis and risk factors. Clin Oral Investig. 2008 Mar;12(Suppl 1):5-13.

28. Reynolds IR. A review of direct orthodontic bonding. Br J Orthod. 1975:2(3):171-8

29. Sheibaninia A, Sepasi S, Saghiri MA, Sepasi S. The effect of an acidic food-simulating environment on the shear bond strength of self-ligating brackets with different base designs. Int J Dent. 2014:2014:689536.

30. Barac R, Gasic J, Trutic N, Sunaric S, Popovic J, Djekic P, et al. Erosive effect of different soft drinks on enamel surface in vitro: application of stylus profilometry. Med Princ Pract. 2015;24(5):451-7.

31. Baka ZM, Akina M, lleria Z, Basciftci FA. Effects of remineralization procedures on shear bond strengths of bracket bonded to demineralized enamel surfaces with self-etch systems. Angle Orthod. 2016 July:86(4):661-7. 